\title{
Analisis Kualitatif Penggunaan Telemedicine sebagai Solusi Pelayanan Kesehatan di Indonesia pada Masa Pandemik COVID-19
}

\author{
Zidni Imanurrohmah Lubis*
}

Departement Fisioterapi, Universitas Muhammadiyah Malang, Jalan Bandung No. 1Malang 65133

*Corresponding author: zidnilubis@ umm.ac.id

\begin{abstract}
ABSTRAK
Kasus penyakit virus corona (COVID-19) muncul pertama kali di Wuhan, Provinsi Hubei, Cina pada Desember 2019 dan telah menyebar ke seluruh dunia termasuk Indonesia. Di Indonesia kasus positif pertama terkonfirmasi pada 2 Maret 2020 dan terus meningkat hingga sekarang. Kebijakan untuk mencegah penyebaran COVID-19 terus dilakukan pemerintah salah satunya dengan menghimbau penggunaan telemedicine. Untuk mengetahui penggunaan telemedicine sebagai solusi pelayanan kesehatan di Indonesia pada masa pandemic COVID-19 dilakukan penelitian analisis kualitatif pada media daring nasional. Analisis data kualitatif dilakukan menggunakan Nvivo12 plus agar dapat memperoleh data konten, klasifikasi data, pemetaan tema, analisis keterkaitan konten, dan word cloud. Hasil analisis uji pearson menunjukkan telemedicine berkorelasi kuat dengan himbauan pemerintah (pearson coefficient correlation $=0.91$ ) yang menjadikan telemedicine solusi pelayanan kesehatan di Indonesia pada masa pandemic COVID-19.
\end{abstract}

Keywords: Covid 19, Pandemik, Pelayanan Kesehatan, Telemedicine, Virus Corona

PENDAHULUAN

Kasus penyakit virus corona (COVID-19) muncul pertama kali di Wuhan, Provinsi Hubei, Cina pada Desember 2019 dan telah menyebar ke seluruh dunia (Chang \& Boudier-Revéret, 2020). Di Indonesia kasus positif pertama terkonfirmasi pada 2 Maret 2020 dan terus meningkat hingga tulisan ini dibuat (Betty, 2020; Ihsanuddin et al., 2020) Pelayanan kesehatan yang belum siap untuk menghadapi COVID-19 menyebabkan peningkatan kasus terus terjadi di Indonesia (Azwar \& Setiati, 2020). Hal tersebut akhirnya membuat Presiden Indonesia mengambil langkah untuk mengimplemen-tasikan Pembatasan Soisal Berskala Besar atau (PSBB) pada Maret 2020 dan beberapa kali diberlakukan kembali di beberapa wilayah yang rentan penyebaran COVID-19. Kebijakan tersebut juga diikuti dengan kebijakan untuk membatasi diri dalam beraktivitas diluar rumah dan bertemu dengan orang (physical distancing) serta himbauan menggunakan platform telemedicine untuk mendapatkan pelayanan kesehatan (Prabowo, 2020; Putra, 2020).

Telemedicine adalah salah satu strategi pencegahan penyebaran COVID19 di banyak negara, karena telemedicine merupakan penyediaan pelayanan kesehatan menggunakan teknologi komunikasi elektronik. Pasien dan tenaga medis tidak perlu bertemu langsung dalam suatu tempat namun tetap berkomunikasi melalui sutau aplikasi. (Chang \& BoudierRevéret, 2020; Prabowo, 2020; Song et al., 2020). Telemedicine terdiri dari beberapa bentuk yaitu konsultasi daring, skrining 
dan chatbot. Dengan beragamnya metode telemedicine, pasien dapat melaporkan gejala yang dirasakan dan mendapatkan saran maupun arahan terkait penyakitnya (Vidal-Alaball et al., 2020). Keuntungan penggunaan telemedicine, selain menjadi solusi bagi pasien untuk mendapatkan penanganan di tengah wabah COVID-19 adalah murah, mudah diakses dan memberikan kenyamanan bagi pasien. Sedangkan bagi tenaga medis dapat membuat pelayanan menjadi efektif dan efisien baik dalam monitoring, evaluating maupun educating. (Turolla et al., 2020; Vidal-Alaball et al., 2020).

Penelitian terdahulu mengungkapkan di mancanegara, telemedicine telah digunakan dalam penanganan kasus pulmonary, musculoskeletal, neurologi (Chang \& Boudier-Revéret, 2020; Cottrell \& Russell, 2020; Gonzalez-Gerez et al., 2020; Randelli \& Compagnoni, 2020; Turolla et al., 2020). Hasil dari penerapan telemedicine sama bahkan lebih memuaskan dibandingkan dengan pelayanan tatap muka pada umumnya. namun sampel penelitian terdahulu hanya sedikit dan tidak ada evaluasi berkelanjutan (Agostini et al., 2015; Bernal et al., 2017; Castrodad et al., 2019; Cottrell et al., 2016; Jiang et al., 2018; Shukla et al., 2016). Sedangkan di Indonesia telemedicine pernah dikembangkan oleh Kementerian Kesehatan sejak 2012 dan bekerja sama dengan pihak ketiga. Aplikasi tersebut dinamakan Telemedisin Indonesia (TEMENIN), namun dalam pemanfaatannya saat pilot project 2017 terkendala oleh kurangnya pemahaman penggunaan teknologi dan pemahaman terkait urgensi penggunaan telemedicine tersebut (Davis, 1989; Nugraheni et al., 2020). Sehingga peneliti tertarik untuk meninjau kembali penggunaan telemedicine dalam situasi yang berbeda yakni di masa pandemic COVID-19 seperti saat ini, dimana pelayanan tatap muka sangat terbatas dan beresiko meningkatkan penyebaran COVID-19.
Penelitian ini diharapkan akan menjawab pertanyaan penelitian, yaitu "Bagaimana telemedicine sebagai solusi pelayanan kesehatan di masa pandemik covid-19 melalui portal berita daring Indonesia?"

\section{METODE}

Penelitian ini menggunakan pendekatan analisis kualitatif konten portal berita daring yang bertujuan untuk menjelaskan penggunaan telemedicine sebagai solusi pelayanan kesehatan di masa pandemi COVID-19. Sampel penelitian ini adalah pemberitaan media online nasional. tentang pemanfaatan telemedicine yang dipublikasikan antara Maret- Juni 2020. Penggunaan sampel disesuaikan dengan kemunculan atau terdeteksinya COVID-19 di Indonesia.

Peneliti menggunakan kata kunci "telemedicine" dan mencari pada empat (4) portal berita daring yang dianggap kredible dan aktif dalam melakukan pemberitaan COVID-19 di Indonesia yakni Kompas.com, Detik.com, Liputan6.com, dan Tempo.co. Berita yang ditemukan kemudian dijadikan objek analisis untuk menjawab pertanyaan penelitian.

Peneliti men-capture objek analisis tersebut menggunakan Ncapture dan melakukan coding serta analisis data menggunakan teknik breaking coding. Breaking coding adalah pengkodean data berdasarkan konsep utama, dimana konsep utama penelitian ini adalah "Telemedicine sebagai solusi pelayanan kesehatan di masa pandemi COVID-19." Berdasarkan konsep tersebut, peneliti mengklasifikasi dan mengkategorisasi data yang ditemukan.

Software Nvivo 12 plus juga digunakan sebagai alat analisis data pada penelitian ini. Fitur-fitur pada Nvivo 12 plus yang digunakan antara lain grafik hierarki untuk mendapatkan data topik yang dominan; tab silang untuk perbandingan topik antar media online; analisis cluster untuk memahami korelasi antar topik; dan frekuensi kata untuk 
memahami konsep utama. Hasil yang diperoleh kemudian dibahas dan dijadikan landasan menjawab pertanyaan penelitian dan menghasilkan konsep dengan diperkuat jurnal-jurnal terbaru terkait telemedicine.

\section{HASIL PENELITIAN}

Hasil penelitian menunjukkan terdapat 10 kata kunci penting terkait "Telemedicine sebagai solusi pelayanan kesehatan di masa pandemi COVID-19" yang ditemukan pada portal media daring nasional di Indonesia. Gambaran kata kunci tersebut diilustrasikan pada Gambar 1 .

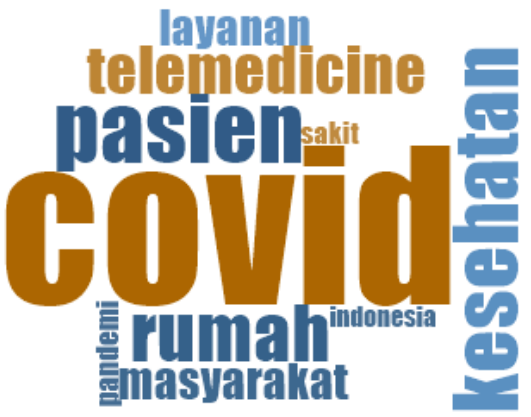

berikut.

Gambar 1. Keyword Cloud pada Media Daring Nasional

Distribusi 5 kata kunci teratas terkait "Telemedicine sebagai solusi pelayanan kesehatan di masa pandemi COVID-19" pada portal media daring nasional disajikan pada Tabel 1. dibawah ini.

Tabel 1. Persentase Kata Kunci Teratas pada Media Daring Nasional

\begin{tabular}{llll}
\hline Kata & Panjang & $\begin{array}{l}\text { Hitung } \\
\text { Kata }\end{array}$ & $\begin{array}{l}\text { Persentase } \\
(\%)\end{array}$ \\
\hline Covid & 5 & 517 & 2.32 \\
\hline Pasien & 6 & 275 & 1.23 \\
\hline Kesehatan & 9 & 265 & 1.19 \\
\hline Rumah & 5 & 244 & 1.09 \\
\hline Telemedicine & 12 & 217 & 0.97 \\
\hline
\end{tabular}

Berdasarkan Gambar 1 dan Tabel 1 diketahui bahwa kata "covid" merupakan kata yang paling banyak disebut yang jumlah hitungnya mencapai 517 pengulangan. Hal ini seiring dengan portal media daring terus membahas perkembangan dari virus yang saat ini masih menjadi pandemic di dunia sejak Desember 2019, dimana new coronavirus ini muncul di Wuhan (Porcher, 2020). Selain itu, kata kunci "rumah" juga berada di posisi 4 teratas. Hal ini berkaitan dengan himbauan pemerintah agar masyarakat tetap di rumah dan mengurangi kegiatan yang menyebabkan kerumunan (Prabowo, 2020; Putra, 2020).

Berdasarkan hasil penelitian pada 4 (empat) portal berita daring nasional yakni Kompas.com, Detik.com, Liputan6.com, dan Tempo.co, topik atau konsep dominan yang relevan dengan "Telemedicine sebagai solusi pelayanan kesehatan di masa pandemi COVID-19" disajikan pada gambar berikut.

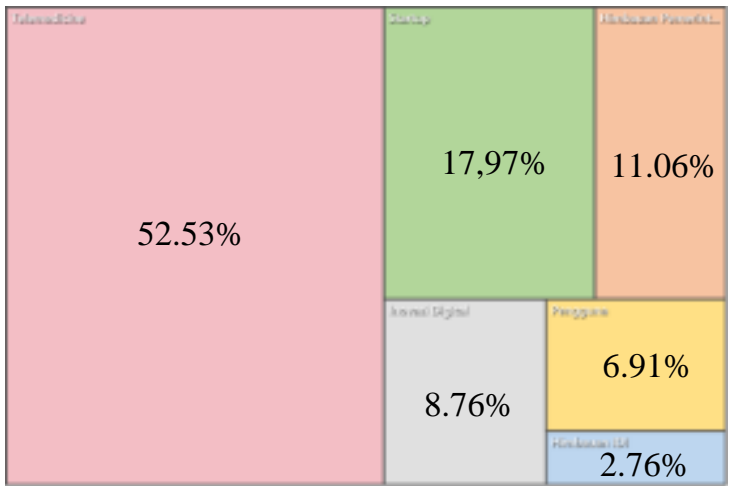

Gambar 2. Konsep Dominan pada Media Daring Nasional

Distribusi topik atau konsep dominan yang relevan dengan "Telemedicine sebagai solusi pelayanan kesehatan di masa pandemi COVID-19" pada portal media daring nasional disajikan pada Tabel 2. dibawah ini.

Tabel 2. Persentase Konsep Dominan pada Media Daring Nasional

\begin{tabular}{|c|c|c|c|c|c|}
\hline \multirow[t]{2}{*}{ Topik } & \multicolumn{4}{|c|}{ Media Daring (\%) } & \multirow{2}{*}{$\begin{array}{l}\text { Total } \\
(\%)\end{array}$} \\
\hline & 1 & 2 & 3 & 4 & \\
\hline Himbauan IDI & 4.55 & 4.35 & 0 & 0 & 2.76 \\
\hline $\begin{array}{l}\text { Himbauan } \\
\text { Pemerintah }\end{array}$ & 6.82 & 15.2 & 18.9 & 0 & 11.06 \\
\hline $\begin{array}{l}\text { Inovasi } \\
\text { Digital }\end{array}$ & 13.6 & 6.52 & 6.9 & 0 & 8.76 \\
\hline Pengguna & 0 & 10.9 & 13.8 & 8 & 6.91 \\
\hline Startup & 25 & 10.9 & 10.3 & 24 & 17.97 \\
\hline Telemedicine & 50 & 52.2 & 50 & 68 & 52.53 \\
\hline
\end{tabular}


Ket : 1: Detik.com; 2: Kompas.com; 3: Liputan6.com ; 4: Tempo.com

Presentase terbesar mengenai konsep dominan yang dibahas adalah telemedicine, yang mencapai 52.53\%. Dan di peringkat kedua ada konsep 'startup' yang mencapai $17.97 \%$. Kedua konsep tersebut relevan dengan topik penelitian "Telemedicine sebagai solusi pelayanan kesehatan di masa pandemi COVID-19" mengingat bentuk dari telemedicine tidak terlepas dari pemanfaatan startup. Aplikasi diharapkan menjadi solusi bagi pasien untuk mendapatkan penanganan di tengah wabah COVID-19 dengan tetap memberikan kenyamanan dan keamanan bagi pasien dan tenaga medis (Turolla et al., 2020; Vidal-Alaball et al., 2020).

Hasil korelasi konsep-konsep dominan terkait telemedicine sebagai solusi pelayanan kesehatan di masa pandemi COVID-19 pada portal media daring nasional disajikan pada Tabel 3. dibawah ini.

Tabel 3. Korelasi Konsep Telemedicine sebagai Solusi Pelayanan Kesehatan di Masa Pandemi Covid-19

\begin{tabular}{lll}
\hline Main Nodes & Nodes & $\mathrm{p}^{*}$ \\
\hline Telemedicine & Himbauan Pemerintah & 0.91 \\
\cline { 2 - 3 } & Startup & 0.90 \\
\cline { 2 - 3 } & Pengguna & 0.83 \\
\cline { 2 - 3 } & Inovasi Digital & 0.72 \\
\cline { 2 - 3 } & Himbauan IDI & 0.60 \\
\hline
\end{tabular}

Ket: *Uji Pearson; $\mathrm{p}=$ Pearson correlation coefficient

Berdasarkan koefisien korelasi Pearson terlihat bahwa pada pemberitaan pada 4 (empat) portal berita daring nasional, konsep terkait telemedicine berkorelasi tertinggi dengan himbauan pemerintah yakni 0.91. Hal ini menunjukkan pemanfaatan telemedicine di masa pandemi semakin meningkat apabila ada peningkatan himbauan pemerintah. Telemedicine juga berkorelasi dengan startup, pengguna, inovasi digital dan himbauan IDI, secara berurutan dengan nilai $0.91,0.90,0.83,0.72,0.60$.
Telemedicine adalah suatu jenis teknologi informasi guna mentransfer informasi medis, diagnosis, terapi dan pendidikan (Perednia, 1995). Transfer informasi dilakukan melalui gambar, video, audio yang interaktif antara pasien dengan tenaga medis (Hong et al., 2020). Selain itu, beberapa fitur dalam aplikasi telemedicine yang dapat dimanfaatkan adalah konsultasi daring, skrining dan chatbot (Vidal-Alaball et al., 2020).

Penggunaan telemedicine oleh tenaga medis dan pasien dapat membuat pelayanan menjadi efektif dan efisien baik dalam monitoring, evaluating maupun educating di masa pandemic seperti saat ini. Dengan beragamnya metode telemedicine, pasien dapat melaporkan gejala yang dirasakan dan mendapatkan saran maupun arahan terkait penyakitnya. Di mancanegara telemedicine telah digunakan dalam penanganan kasus pulmonary, musculoskeletal, neurologi (Chang \& Boudier-Revéret, 2020; Cottrell \& Russell, 2020; Gonzalez-Gerez et al., 2020; Randelli \& Compagnoni, 2020; Turolla et al., 2020; Vidal-Alaball et al., 2020).

Sebagai upaya pencegahan penyebaran COVID-19, pemerintah di Indonesia aktif menghimbau masyarakat dan tenaga medis untuk menggunakan hasil startup berupa telemedicine sebagai aplikasi layanan kesehatan masyarakat jarak jauh atau online antara rumah sakit dan pasien (Machmud et al., 2020). Namun dalam penyelenggaraannya, ada beberapa tantangan yang muncul seperti kemampuan teknologi, keamanan data dan privasi pasien, peraturan perundangan, pedoman penggunaan dan masalah pasien secara individu itu sendiri (Hikmahwati \& Sulistiadi, 2020). Sehingga, dalam hal pemanfaatan telemedicine, pemerintah harus tetap hadir dalam penentuan kebijakan dan menjalin kerja sama dengan rumah sakit dan tenaga medis secara berkelanjutan (Hikmahwati \& Sulistiadi, 2020; Machmud et al., 2020). 


\section{KESIMPULAN}

Berdasarkan hasil yang diperoleh dari portal media daring nasional, dapat disimpulkan bahwa telemedicine telah digunakan sebagai salah satu solusi pelayanan kesehatan di masa pandemik covid-19 dan berkorelasi kuat dengan himbauan pemerintah dan startup. Diharapkan penelitian selanjutnya bisa fokus terhadap pemanfaatan telemedicine dalam pelayanan kefisioterapian dan kepuasan pengguna baik tenaga medis maupun pasien di masa pandemic covid19.

\section{DAFTAR PUSTAKA}

Agostini, M., Moja, L., Banzi, R., Pistotti, V., Tonin, P., Venneri, A., \& Turolla, A. (2015). Telerehabilitation and Recovery of Motor Function: a Systematic Review and MetaAnalysis. Journal of Telemedicine and Telecare, 21(4), 202-213. https://doi.org/10.1177/1357633X155 72201

Azwar, M. K., \& Setiati, S. (2020). COVID-19 and Indonesia. Acta Med Indones-Indones J Intern Med, 52(1), 84-89.

https://www.researchgate.net/publicat ion/340645813

Bernal, J. M. P., Valero, R. M., López, F. J. B., \& Pérez, M. J. E. (2017). Evidence of Benefit of Telerehabitation after Orthopedic Surgery: A Systematic Review. In Journal of Medical Internet Research (Vol. 19, Issue 4). Journal of Medical Internet Research. https://doi.org/10.2196/jmir.6836

Betty, T. T. S. (2020, March). Kasus Pertama Virus Corona di Indonesia Jadi Sorotan Dunia - Global Liputan6.com. Liputan 6. https://www.liputan6.com/global/read /4191815/kasus-pertama-viruscorona-di-indonesia-jadi-sorotandunia
Castrodad, I. M. D., Recai, T. M., Abraham, M. M., Etcheson, J. I., Mohamed, N. S., Edalatpour, A., \& Delanois, R. E. (2019). Rehabilitation Protocols Following Total Knee Arthroplasty: a Review of Study Designs and Outcome Measures. Annals of Translational Medicine, 7(S7), $\mathrm{S} 255-\mathrm{S} 255$. https://doi.org/10.21037/atm.2019.08. 15

Chang, M. C., \& Boudier-Revéret, M. (2020). Usefulness of telerehabilitation for stroke patients during the COVID-19 pandemic. American Journal of Physical Medicine \& Rehabilitation, Publish Ah, 1-5. https://doi.org/10.1097/phm.0000000 000001468

Cottrell, M. A., Galea, O. A., O'Leary, S. P., Hill, A. J., \& Russell, T. G. (2016). Real Time Telerehabilitation for the Treatment of Musculoskeletal Conditions is Effective and Comparable to Standard Practice: A Systematic Review and Meta Analysis. In Clinical Rehabilitation (Vol. 31, Issue 5, pp. 625-638). SAGE Publications Ltd. https://doi.org/10.1177/02692155166 45148

Cottrell, M. A., \& Russell, T. G. (2020). Telehealth for musculoskeletal physiotherapy. Musculoskeletal Science and Practice, January.

Davis, F. . (1989). Perceived Usefulness, Perceived Ease of Use, and User Acceptance of Information Technology. MIS Quarterly, 13(3), 319-340.

Gonzalez-Gerez, J. J., Utrera, C. B., Anarte-Lazo, E., García-Vidal, J. A., Botella-Rico, J. M., \& RodriguezBlanco, C. (2020). Therapeutic Pulmonary Telerehabilitation Protocol in Patients Affected by COVID-19, Confined in Their Homes: Study Protocol for a Randomized Control Trial. Research 
Square, $1-19$. https://doi.org/10.21203/rs.3.rs24617/v1

Hikmahwati, \& Sulistiadi, W. (2020). A Systematic Review: Challenges and Evaluations Related to Telemedicine as a Healthcare's Hope to Tackle COVID-19. In Hikmahwati \& W. Sulistiadi (Eds.), Proceedings of the International Conference of Health Development. Covid-19 and the Role of Healthcare Workers in the Industrial Era (ICHD 2020) (pp. 194-201). Atlantis Press. https://doi.org/10.2991/ahsr.k.201125 .033

Hong, Z., Li, N., Li, D., Li, J., Li, B., Xiong, W., Lu, L., Li, W., \& Zhou, D. (2020). Telemedicine during the COVID-19 pandemic: Experiences from Western China. Journal of Medical Internet Research, 22(5), 15.

https://doi.org/https://doi.org/10.2196 $/ 19577$

Ihsanuddin, Sari, H. P., \& Mashabi, S. (2020, July 5). UPDATE 4 Juli: Tambah 1.447, Total Ada 62.142 Kasus Covid-19 di Indonesia. Kompas.

https://nasional.kompas.com/read/202 0/07/04/15430201/update-4-julitambah-1447-total-ada-62142-kasuscovid-19-di-indonesia

Jiang, S., Xiang, J., Gao, X., Guo, K., \& Liu, B. (2018). The Comparison of Telerehabilitation and Face-to-Face Rehabilitation after Total Knee Arthroplasty: A Systematic Review and Meta-Analysis. Journal of Telemedicine and Telecare, 24(4), 257-262.

https://doi.org/10.1177/1357633X166 86748

Machmud, M., Masmuh, A., Nasirin, C., Salahudin, Baharuddin, T., \& Musa, A. E. Z. (2020). Artificial Intelligence In The Public Health Sector: The Use Of Telemedicine In Indonesia During Covid-19 | PalArch's Journal of
Archaeology of Egypt / Egyptology. PalArch's Journal of Archaeology of Egypt, 17(7), 10106-10118. https://archives.palarch.nl/index.php/j ae/article/view/4047

Nugraheni, R., Sanjaya, G. Y., Putri, S. S. M., Fuad, A., Lazuardi, L., Pertiwi, A. A. P., Sumarsono, S., \& Sitaresmi, M. N. (2020). Low Utilization of Telemedicine in the First-Year Trial: A Case in the Province of West Papua, Indonesia. 22(Ishr 2019), 568-571.

https://doi.org/10.2991/ahsr.k.200215 .110

Perednia, D. A. (1995). Telemedicine Technology and Clinical Applications. The Journal of the American Medical Association, 273(6), 483-488. https://doi.org/https://doi.org/10.1001 /jama.273.6.483

Porcher, S. (2020). Response2covid19, a Dataset of Governments' Responses to COVID-19 All Around the World. Scientific Data, 7(1), 1-9. https://doi.org/10.1038/s41597-02000757-y

Prabowo, D. (2020, April 6). 19 Dokter Meninggal Selama Pandemi Covid19, IDI Rekomendasikan Platform Telemedicine.

Kompas. https://nasional.kompas.com/read/202 0/04/06/13425551/19-doktermeninggal-selama-pandemi-covid-19idi-rekomendasikan-platform

Putra, P. M. S. (2020, March 30). Menko PMK: Jokowi Setujui Aturan Karantina Wilayah di Tingkat Daerah - News Liputan6.com. Liputan 6. https://www.liputan6.com/news/read/ 4214913/menko-pmk-jokowi-setujuiaturan-karantina-wilayah-di-tingkatdaerah

Randelli, P. S., \& Compagnoni, R. (2020). Management of orthopaedic and traumatology patients during the Coronavirus disease (COVID-19) pandemic in northern Italy. Knee 
Surgery, Sports Traumatology,

Arthroscopy, 28(6), 1683-1689. https://doi.org/10.1007/s00167-02006023-3

Shukla, H., Nair, S. R., \& Thakker, D. (2016). Role of Telerehabilitation in Patients Following Total Knee Arthroplasty: Evidence from a Systematic Literature Review and Meta-Analysis. Journal of Telemedicine and Telecare, 23(2), 339-346.

https://doi.org/10.1177/1357633X166 28996

Song, X., Liu, X., \& Wang, C. (2020). The role of telemedicine during the COVID-19 epidemic in China Experience from Shandong province. Critical Care, 24(1), 1-4. https://doi.org/10.1186/s13054-02002884-9

Turolla, A., Rossettini, G., Viceconti, A., Palese, A., \& Tommaso, G. (2020). Musculoskeletal Physical Therapy During the COVID-19 Pandemic: Is Telerehabilitation the Answer. Oxford University Press.

Vidal-Alaball, J., Acosta-Roja, R., Pastor Hernández, N., Sanchez Luque, U., Morrison, D., Narejos Pérez, S., Perez-Llano, J., López Seguí, F., \& Salvador Vèrges, A. (2020). Telemedicine in the face of the COVID-19 pandemic. Atencion Primaria, 52(6), 418-422. https://doi.org/10.1016/j.aprim.2020.0 4.003 